\title{
The Amelioration of Post Tin Mining Sand Tailing Medium with Chicken Manure for Pepper Cultivation
}

\author{
Ameliorasi Media Tailing Pasir Pasca Penambangan Timah dengan Pupuk Organik \\ Kotoran Ayam untuk Budidaya Lada \\ Ismed Inonu $^{1 *}$, Riwan Kusmiadi ${ }^{1}$, Ayu Yuliana ${ }^{1}$, Eddy Nurtjahya ${ }^{2}$ \\ ${ }^{1}$ Department of Agrotechnology, Bangka Belitung University, Bangka 33172 \\ ${ }^{2}$ Department of Biology, Bangka Belitung University, Bangka 33172 \\ ${ }^{*}$ Correspondent author: ismedinonu8@gmail.com
}

(Received: 19 September 2019, Accepted: 25 March 2020)

Citation: Inonu I, Kusmiadi R, Yuliana A, Nurtjahya E. 2020. The amelioration of post tin mining sand tailing medium with chicken manure for pepper cultivation. Jurnal Lahan Suboptimal: Journal of Suboptimal Lands 9(1): 31-40.

\begin{abstract}
ABSTRAK
Budidaya lada di lahan tailing bekas tambang timah memerlukan ameliorasi bahan organik untuk memperbaiki karakteristik tanah. Penelitian ini bertujuan untuk mengetahui pengaruh berbagai dosis pupuk organik kotoran ayam terhadap pertumbuhan tiga varietas lada di media tailing pasir. Penelitian dilakukan pada bulan April sampai dengan Agustus 2016 di lahan Kebun Percobaan dan Penelitian Universitas Bangka Belitung. Penelitian menggunakan percobaan dengan rancangan acak lengkap faktorial dua faktor dan tiga ulangan. Faktor pertama berupa dosis pupuk organik kotoran ayam $(5 ; 6 ; 77 \mathrm{~kg} / \mathrm{tanaman})$ dan faktor kedua berupa varietas lada (Lampung Daun Lebar; Lampung Daun Kecil; Merapin). Hasil penelitian menunjukkan dosis pupuk organik berpengaruh tidak nyata terhadap hamper semua variebel pertumbuhan, kecuali luas daun. Varietas lada berpengaruh nyata hanya pada variabel klorofil total, bobot kering akar dan bobot kering pucuk. Tidak terdapat pengaruh interaksi antara dosis pupuk dan varietas. Terdapat kecenderungan varietas Lampung Daun Lebar lebih baik pertumbuhannya dibandingkan dua varietas lainnya pada media tailing pasir.
\end{abstract}

Kata kunci: dosis, Piper nigrum L, pupuk organik

\begin{abstract}
Pepper cultivation in tin mining sand tailings requires the amelioration of organic matter to improve soil characteristics. The paper investigates the effect of chicken manure dosage on the growth of three pepper cultivars in sand tailing medium. This study was conducted on April-August 2016 at Experiment Station of Universitas Bangka Belitung, Balunijuk Village, Bangka Island. This study was arranged in a completely randomized design with two factors and three replications. The first factor was the dosage of chicken manure $(5 \mathrm{~kg}$; $6 \mathrm{~kg} ; 7 \mathrm{~kg} /$ plant). The second factor was pepper cultivars (Lampung Daun Lebar; Lampung Daun Kecil; Merapin). The. result of the analysis of variance showed that the treatment of chicken manure dosage significantly affected only on total leaf area. The treatment of pepper cultivars significantly affected the total of chlorophyll, root dry weight, and shoot dry weight. There was no interaction between chicken manure dosage and pepper cultivar.
\end{abstract}


Pepper cv. Lampung Daun Lebar tends to grow better than the other cultivars in the sand tailing medium.

Keywords: dosage, organic matter, Piper nigrum L

\section{INTRODUCTION}

Bangka Island is the largest tinproducing island in Indonesia. The area of tin mineral mining license (IUP) onshore is 236,390.33 ha (PT. Timah 2016). Center for Research and Development of Agricultural Land Resources (2016) reported that about 79,163 ha of tin mining land on Bangka Island, while according to Sukarman and Agustian (2016), 80,018 ha of ex-tin mining land on Bangka Island consisted of 72,400 ha of land area $(90,48 \%)$ and ex-mining pit about 7.618 ha $(9,52 \%)$. One of the impacts of tin mining activity is the formation of tailings land. The tin mine tailings land has a low soil fertility status, indicated by the dominance of the sand fraction and low soil $\mathrm{pH}$, organic carbon, cation exchange capacity, and essential macronutrients (Asmarhansyah et al., 2017).

Sand tailing typical sand fractional composition of sand $92 \%$, silt $2 \%$, and clay 6\% (Inonu et al., 2011). High sand fraction content causes higher porosity and lower water holding capacity. The $\mathrm{pH}$ of the sand tailings is acidic, about $\mathrm{pH}$ 5. The nutrient content of the sand tailings, especially nitrogen, phosphorus, and potassium, is relatively low. The $\mathrm{N}$ content in sand tailings is $0.01 \%, \mathrm{P}$ is $0.15 \%$, and $\mathrm{K}$ is $0.03 \%$ (Tjahyana \& Ferry, 2011).

The potential of the sand tailings land is currently not utilized. From a technical perspective, the former mining area can be used for agricultural cultivation if land conditions have been improved, and then it can be used for productive purposes such as agriculture (Dariah et al., 2010), such as a pepper cultivation area. Pepper is a traditional commodity of Bangka Island. According to the Central Statistics Agency of the Bangka Belitung Archipelago Province (2019), the total planting area of pepper is $4,036.17$ ha, with its production of 3,447.82 tons. Tailings can be used to increasing the cultivation area of pepper. One approach to support the growth of pepper plantation in the sand tailings media is the amelioration of organic matter. Organic matter is useful to improving the physical, chemical, and biology characteristics of the ex-tin mining area. According to Suriadikarta and Setyorini (2005), chicken manure contains macronutrients such as $\mathrm{N}$ of $1,17 \%, \mathrm{P} 2 \mathrm{O} 5$ of $1,87 \%$, and $\mathrm{K} 2 \mathrm{O}$ of $0,06 \%$. Nurcholis et al. (2013) stated that amendments to the post tin mining land with a mixture of organic matter, clay, and NPK fertilizer resulted the best sorghum production. According to Nurbaity et al. (2017), the application of manure and mycorrhizae increased the content of C-organic, $\mathrm{N}$-total, $\mathrm{C} / \mathrm{N}$ of post-mining sand tailing and increased the length of shoots of super red dragon fruit significantly. Inonu et al. (2014), doses of organic fertilizer (chicken manure) affect the growth and production of pakchoy in the sand tailings land. A dose of 45 tons of organic fertilizer/ha produces the best pakchoy production. Santi (2016) found a dose of $5 \mathrm{~kg}$ of manure/planting hole produced the best growth and production of citronella in post-mining land.

Research by Haryati et al. (2019) found out that giving a mixture of biochar husk and manure (1:1) 25 tons/ha gave the highest yield of cayenne pepper in the land of the former tin mined soil. In addition to improving soil characteristics by amelioration of organic matter, pepper cultivation in tailings requires adaptive pepper cultivars. For this reason, testing of several superior cultivars of the pepper in the sand tailing media is needed. Pepper cultivars that will be used in this study are the Lampung Daun Lebar (LDL), Lampung Daun Kecil (LDK), and Merapin Daun Lebar (MDL). LDL cultivar is slightly tolerant of low fertility soil (Sarpian 2003). LDK cultivar has smaller leaf shapes than LDL. This cultivar is relatively resistant to 
the yellow disease of pepper (Nurhakim 2014). The MDL is a pepper cultivar that is more favourable among farmers in Bangka Belitung because this cultivar produces the fruit continuously throughout the season and is relatively resistant to disease (IAARD, 2015). According to Handara (2011), each cultivar shows different results of growth. The purpose of this experiment was to study the effect of chicken manure doses on the growth of three pepper cultivars in the sand tailings media. Furthermore, the results of this study are expected to be a reference to obtain adaptive and resistant cultivar of pepper in sand tailings media and to obtain a proper dose of chicken manure for pepper growth in sand tailings media.

\section{MATERIALS AND METHODS}

This study was conducted at Experiment Station of Universitas Bangka Belitung, Balunijuk Village, Bangka Island.on AprilAugust 2016. The equipments used in this study include, analytical scales and portable leaf area meters C1-202. The research material consisted of 3-month-old cultivar obtained from farmers' pepper plantations in Kemuja Village, Bangka Regency, the sand tailings were taken from the reclamation site of the ex-tin mining located in the Air Jangkang Site, Dwi Makmur Village, Bangka Regency. The other materials were topsoil, chicken manure, and $45 \mathrm{~cm} \mathrm{x} 45 \mathrm{~cm}$ of polybags.

This study used an experimental method, using a completely randomized design with 2 factors and 3 replications. The first treatment factor is the dose of chicken manure, consisting of 5,6 , and $7 \mathrm{~kg}$ per polybag. The second treatment factor was pepper cultivar, consisting of Lampung Daun Lebar (LDL), Lampung Daun Kecil (LDK) and Merapin Daun Lebar (MDL).

The research site is cleared from weeds. Manual tillage was done using a hoe and ground fork. Growing media in the form of a mixture of $5.3 \mathrm{~kg}$ tailings, $3.7 \mathrm{~kg}$ of soil (topsoil), and manure according to the dose per polybag. The media is mixed evenly by stirring using a hoe so that it is homogeneous. The media was then loaded into the polybags which were arranged according to the layout of the experimental design. Furthermore, the media was incubated for 2 weeks in the field. Planting material in the form of pepper seedlings Pepper seeds that have been prepared are then planted into a polybag containing the planting medium. Each polybag planted with one seed. Each repetition consisted of 3 polybags, so there are 81 polybags containing pepper plants. The media is compacted and watered to field capacity. Plant maintenance consists of the provision of temporary shading, weeding, piling, watering, fertilizing, and replanting. Variables observed in this study consist of 1) increase in plant height $(\mathrm{cm}), 2)$ increase in stem diameter $(\mathrm{mm}), 3)$ increase in number of leaves, 4) total chlorophyll $(\mathrm{mg} / \mathrm{g}), 5)$ increase in leaf area $(\mathrm{cm} 2), 6)$ shoot biomass ( $\mathrm{g}$ ), and root biomass. and 7) analysis of soil chemical properties. Observation data were analyzed using analysis of variance at $\alpha 5 \%$ using a computer program. If it has a significant effect, it will be followed by DMRT (Duncan's Multiple Range Test).

\section{RESULTS}

The results of the chemical analysis of the sand tailings and topsoil used are presented in Table 1 The chemical fertility status of sand tailings is very low to low. This is shown by low $\mathrm{pH}, \mathrm{C}$-organic content, total $\mathrm{N}$, and total $\mathrm{P}_{2} \mathrm{O}_{5}$. The exchangeable cations (K-ec, $\mathrm{Ca}-\mathrm{ec}, \mathrm{Mg}-\mathrm{ec}$ ) which are very low, cation exchange capacity is low, and acidic cations content Al-ec and $\mathrm{H}-\mathrm{ec}$ are hight. Chemical properties of topsoil generally have low to very low, except organic-C. Based on Table 2, in general, chicken manure used contains macronutrients ( $\mathrm{P}, \mathrm{K}, \mathrm{Ca}, \mathrm{Mg}, \mathrm{S}$ ) and micro ( $\mathrm{Fe}, \mathrm{B}, \mathrm{Mn}, \mathrm{Zn}, \mathrm{Na}, \mathrm{Cu}$ ). The macronutrient content of phosphorus is higher than potassium. Phosphorus content is $0.97 \%$ and potassium is $0.31 \%$. The nutrient content of phosphorus and 
potassium in the media used is classified as moderate, based on Indonesian National Standard of organic manure. Based on the results of the analysis of variance (Table 3 ), it was shown that the manure dosage treatment did not significantly affect all observed variables, except the leaf area. The cultivar showed no significant effect on all variables, except the total chlorophyll, root biomass, and shoot biomass. Meanwhile, interactions of the treatment of cultivar and manure doses showed no significant effect on all variables observed.

\section{Effect of Manure Dosage}

The results of the pepper growth rate from the 4th week to the 16th week after planting are shown in Figure 1. In the plant height (Figure 1A) it is shown that the $5 \mathrm{~kg}$ dose treatment resulted in the highest increase in the $8^{\text {th }}$ week after planting. In the $12^{\text {th }}$ to $16^{\text {th }}$ week after planting, the 6 $\mathrm{kg}$ manure does treatment produced the highest plant height. The $7 \mathrm{~kg}$ manure does treatment produced the higher stem diameter growth rate regularly (Figure 1B).

Table 1. The initial chemical properties of the sand tailings and topsoil used in the experiment

\begin{tabular}{|c|c|c|c|}
\hline \multirow{2}{*}{ Chemical Properties } & \multicolumn{2}{|c|}{ Media } & \multirow{2}{*}{ Method } \\
\hline & Sand Tailing & Topsoil & \\
\hline Cation Exchange capacity & & & Titrimetri \\
\hline$(\operatorname{cmol}(+) / \mathrm{kg})$ & $1.96(\mathrm{VL})$ & $9.28(\mathrm{~L})$ & \\
\hline Ca-dd $(\operatorname{cmol}(+) / k g)$ & 0.05 (VL) & $0.79(\mathrm{VL})$ & AAS \\
\hline $\operatorname{Mg}-\mathrm{dd}(\mathrm{cmol}(+) / \mathrm{kg})$ & $0.24(\mathrm{VL})$ & $0.70(\mathrm{~L})$ & AAS \\
\hline $\mathrm{K}-\mathrm{dd}(\mathrm{cmol}(+) / \mathrm{kg})$ & $0.05(\mathrm{VL})$ & $0.08(\mathrm{VL})$ & AAS \\
\hline $\mathrm{Na}-\mathrm{dd} \mathrm{cmol}(+) / \mathrm{kg})$ & $0.01(\mathrm{VL})$ & $0.03(\mathrm{M})$ & AAS \\
\hline $\mathrm{pH}\left(\mathrm{H}_{2} \mathrm{O}\right)$ & 5.28 (acid) & 4.85 (acid) & \\
\hline $\mathrm{pH}(\mathrm{KCl})$ & 5.12 (acid) & 4.72 (acid) & \\
\hline Total-N (\%) & $0.01(\mathrm{VL})$ & $0.16(\mathrm{~L})$ & Kjeldahl \\
\hline Organic C $(\%)$ & $0.08(\mathrm{VL})$ & $2.11(\mathrm{M})$ & Walkley and Black \\
\hline $\operatorname{Al}-d d(\operatorname{cmol}(+) / \mathrm{kg})$ & 0.21 & 2.81 & \\
\hline $\mathrm{H}-\mathrm{dd}(\mathrm{cmol}(+) / \mathrm{kg})$ & 0.17 & 0.43 & \\
\hline Total $\mathrm{P}_{2} \mathrm{O}_{5}\left(\mathrm{mg} \mathrm{P}_{2} \mathrm{O}_{5} / 100 \mathrm{~g}\right)$ & $0.07(\mathrm{VL})$ & $29.97(\mathrm{M})$ & Spectrophotometer UV-VIS \\
\hline Total $\mathrm{K}_{2} \mathrm{O}\left(\mathrm{mg} \mathrm{K}_{2} \mathrm{O} / 100 \mathrm{~g}\right)$ & $0.33(\mathrm{VL})$ & $0.44(\mathrm{VL})$ & AAS \\
\hline available $-\mathrm{K}_{2} \mathrm{O} 5(\mathrm{ppm})$ & 13.07 & 65.47 & Spectrophotometer UV-VIS \\
\hline $\mathrm{Pb}(\mathrm{ppm})$ & $<0.005$ & 8.21 & AAS \\
\hline $\mathrm{Cd}(\mathrm{ppm})$ & $<0.056$ & $<0.056$ & AAS \\
\hline $\mathrm{Hg}(\mathrm{ppb})$ & $<10.764$ & 185.04 & AAS \\
\hline
\end{tabular}

Note: according to the Soil Research Center (1983), VL = very low, $\mathrm{L}=$ low, $\mathrm{M}=$ medium

Table 2. Nutrient content status of chicken manure used in an experiment

\begin{tabular}{lrc}
\hline \multirow{2}{*}{ Elements } & \multicolumn{2}{c}{ Organic Matter } \\
\cline { 2 - 3 } & Chicken Manure & SNI 19-7030-2004 \\
\hline Macro & & \\
$\mathrm{P}(\%) *$ & 0.97 & 0.10 \\
$\mathrm{~K}(\%) * *$ & 0.31 & 0.20 \\
$\mathrm{Ca}(\%) * *$ & 0.66 & - \\
$\mathrm{Mg}(\%) * *$ & 0.17 & - \\
$\mathrm{S}(\%) *$ & 0.04 & - \\
$\mathrm{Micro}$ & & \\
$\mathrm{Fe}(\mathrm{ppm}) * *$ & 892.3 & - \\
$\mathrm{B}(\mathrm{ppm}) *$ & 6.85 & - \\
$\mathrm{Mn}(\mathrm{ppm}) * *$ & 12.48 & - \\
$\mathrm{Zn}(\mathrm{ppm}) * *$ & 4.22 & 500 \\
$\mathrm{Na}(\%) * *$ & 0.02 & - \\
$\mathrm{Cu}(\mathrm{ppm}) * *$ & 15.99 & 100 \\
\hline
\end{tabular}

Note: Soil sample extracting with $\mathrm{HNO}_{3} 65 \%+\mathrm{HCl}_{4} 60 \%$ for macro elements and microelements

*) analysis with spectrophotometer UV-VIS method, **) analysis with the AAS method 
Variable number of leaves increased regularly on a dose of $6 \mathrm{~kg}$ (Figure 1C). Likewise, the variable number of nodes (Figure 1D) showed a significant increase from the $4^{\text {th }}$ week. to the $16^{\text {th }}$ week after planting. In Figure $1 \mathrm{C}$, the $6 \mathrm{~kg}$ does manure treatment shows a wider leaf area and is significantly differed to the $5 \mathrm{~kg}$ manure dose and the $7 \mathrm{~kg}$ dose (Table 4). However, the $5 \mathrm{~kg}$ treatment was not significantly differed to a $7 \mathrm{~kg}$ of manure dose.

Table 3. Analysis of variance of the effect of chicken manure dose on the growth of three pepper cultivars in sand tailing media

\begin{tabular}{|c|c|c|c|c|c|c|c|}
\hline \multirow[b]{2}{*}{ Variables } & \multicolumn{2}{|c|}{ Doses } & \multicolumn{2}{|c|}{ Cultivar } & \multicolumn{2}{|c|}{ Interaction } & \multirow[t]{2}{*}{$\mathrm{CV}(\%)$} \\
\hline & F Value & $\operatorname{Pr}>\mathrm{F}$ & F Value & $\operatorname{Pr}>\mathrm{F}$ & F Value & $\operatorname{Pr}>\mathrm{F}$ & \\
\hline Plant Height $(\mathrm{cm})$ & $0.54^{\mathrm{ns}}$ & 0.5932 & $1.06^{\mathrm{tn}}$ & 0.3692 & $1.25^{\mathrm{tn}}$ & 0.3293 & 31.85423 \\
\hline Stem Diameter (mm) & $0.25^{\mathrm{ns}}$ & 0.7835 & $0.13^{\text {th }}$ & 0.8804 & $1.28^{\text {tn }}$ & 0.3167 & 37.39488 \\
\hline Number of Leaves (sheet) & $1.11^{\mathrm{ns}}$ & 0.3509 & $1.85^{\mathrm{tn}}$ & 0.1872 & $0.40^{\operatorname{tn}}$ & 0.8072 & 60.93017 \\
\hline Number of Nodes & $0.68^{\mathrm{ns}}$ & 0.5190 & $1.19^{\mathrm{tn}}$ & 0.3281 & $0.49^{\text {tn }}$ & 0.7449 & 51.09660 \\
\hline Total Chlorophyll (mg/g) & $4.38^{\mathrm{ns}}$ & 0.0292 & $2.34 *$ & 0.1262 & $1.60^{\mathrm{tn}}$ & 0.2197 & 25.42526 \\
\hline Leaves Area $\left(\mathrm{cm}^{2}\right)$ & $5.36^{*}$ & 0.0156 & $2.89^{\operatorname{tn}}$ & 0.0834 & $0.90^{\operatorname{tn}}$ & 0.4834 & 53.11214 \\
\hline Root Biomass (g) & $0.27^{\mathrm{ns}}$ & 0.7678 & $6.97 *$ & 0.0061 & $1.29^{\mathrm{tn}}$ & 0.3145 & 53.00834 \\
\hline Shoot Biomass (g) & $0.48^{\mathrm{ns}}$ & 0.6253 & $6.61 *$ & 0.0075 & $0.31^{\mathrm{tn}}$ & 0.8691 & 41.36787 \\
\hline
\end{tabular}

Note: ns : no significant, Pr>F : probality , *: significant, CV: coeffient of varians

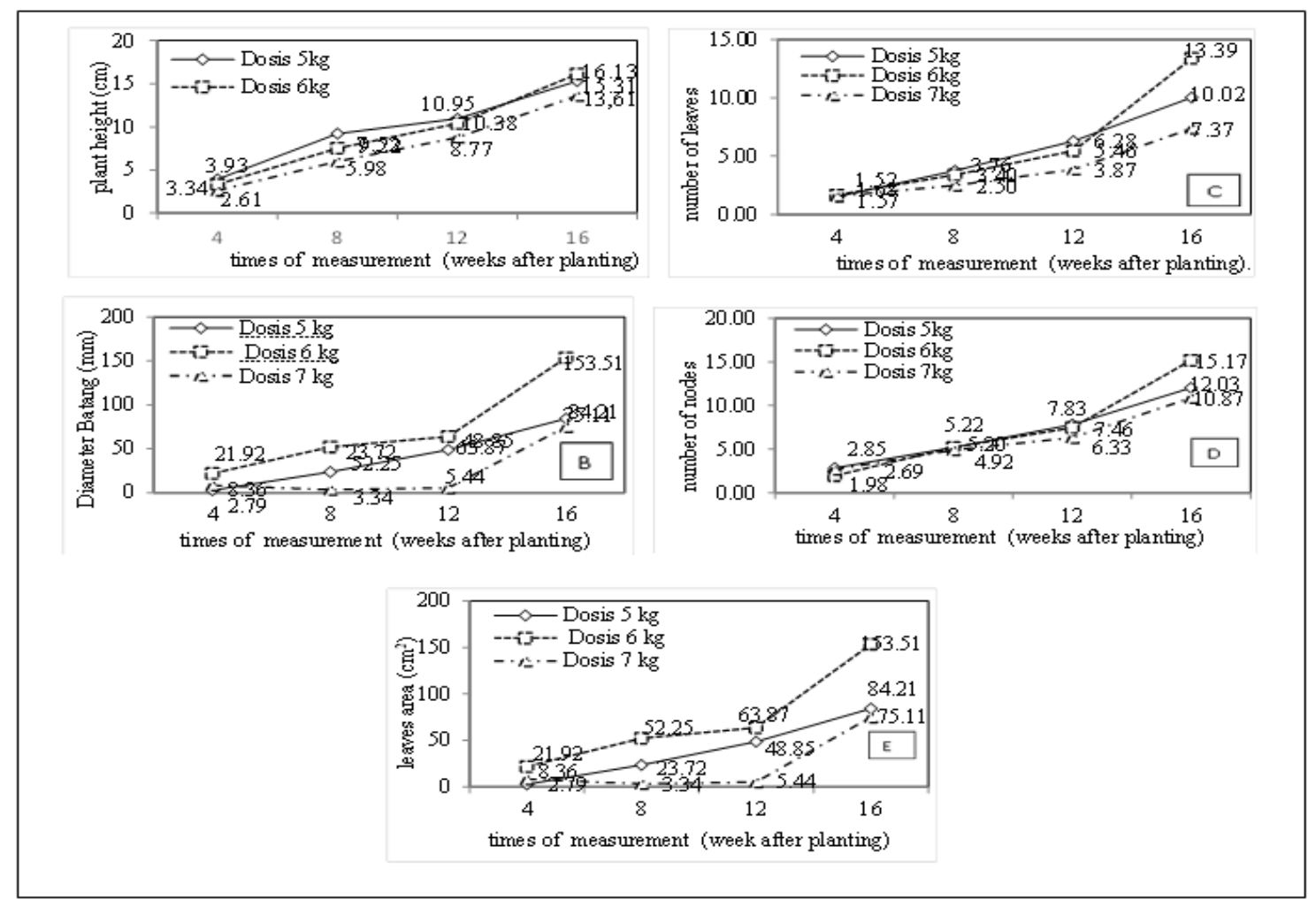

Figure 1. Increase in plant height (A), stem diameter (B), number of leaves (C), number of nodes (D) and leaves area (E) of pepper in the tailings media with various doses of chicken manure on the 4-16th after planting

Table 4. Effect of chicken manure dose on leaves area $\left(\mathrm{cm}^{2}\right)$

\begin{tabular}{lc}
\hline Chicken Manure Dose & Leaves Area $\left(\mathrm{cm}^{2}\right)$ \\
\hline $5 \mathrm{~kg}$ & $84.21^{\mathrm{b}}$ \\
$6 \mathrm{~kg}$ & $153.51^{\mathrm{a}}$ \\
$7 \mathrm{~kg}$ & $75.11^{\mathrm{b}}$ \\
\hline
\end{tabular}

Note: The numbers followed by the same letters in the same column show no significant difference in Duncan's Multiple Range Test (DMRT) $\alpha=5 \%$ 


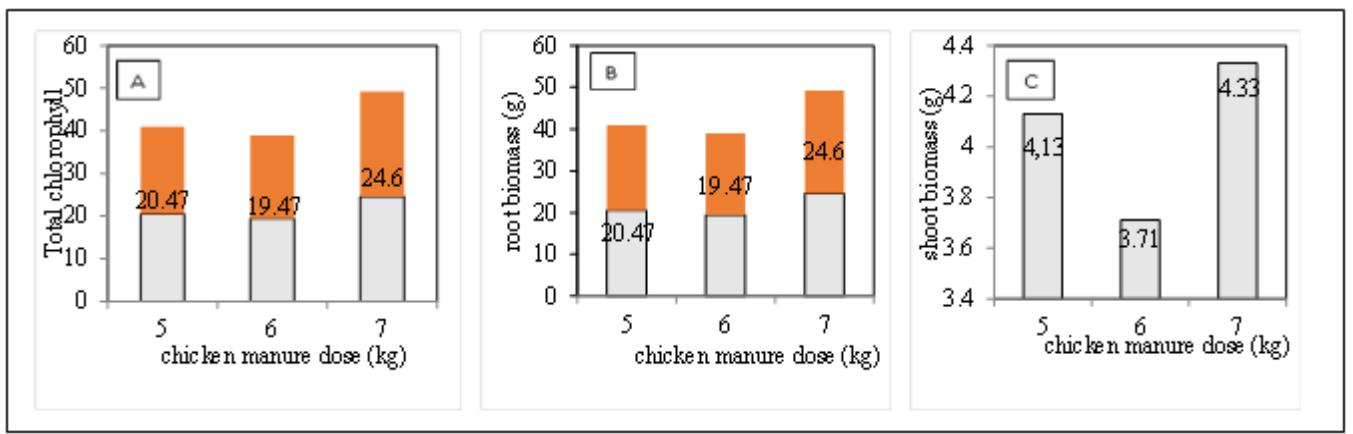

Figure 2.Total chlorophyll, root biomass, and shoot biomass of pepper in various of chicken manure doses media

Table 5. Effect of three cultivars of pepper on total chlorophyll, root biomass, and shoot biomass of pepper

\begin{tabular}{lccc}
\hline Cultivars & Total Chlorophyll $(\mathrm{mg} / \mathrm{g})$ & Root Biomass $(\mathrm{g})$ & Shoot Biomass $(\mathrm{g})$ \\
\hline Lampung Daun Lebar & $25.065_{\mathrm{a}}$ & $0.6250_{\mathrm{a}}$ & $5.2875_{\mathrm{a}}$ \\
Lampung Daun Kecil & $17.529_{\mathrm{b}}$ & $0.4889_{\mathrm{a}}$ & $4.5111_{\mathrm{a}}$ \\
Merapin Daun Lebar & $22.010_{\mathrm{ab}}$ & $0.2222_{\mathrm{b}}$ & $2.4889_{\mathrm{b}}$ \\
\hline
\end{tabular}

Note: The numbers followed by the same letters in the same column show no significant difference in Duncan's Multiple Range Test (DMRT) $\alpha=5 \%$

The effect of doses of manure on total chlorophyll, root biomass, and shoot biomass is shown in Figure 2. In the total chlorophyll, the treatment of $7 \mathrm{~kg}$ manure dosage shows a higher total chlorophyll than the dose of $5 \mathrm{~kg}$ and $6 \mathrm{~kg}$ manure (Figure 2A). The dosage of manure $7 \mathrm{~kg}$ have the highest increase of root biomass (Figure 2B) and shoot biomass (Figure 2C).

\section{Effects of Cultivar}

The results of observations of the growth rate of three pepper cultivars from the $4^{\text {th }}$ week to the $16^{\text {th }}$ week after planting are shown in Figure 3. The LDK cultivar produced the highest increase in plant height (3A), the largest stem diameter (3B), and the highest number of segments (3D). However, on the variable number of leaves and leaf area, LDL cultivar shows a faster increase than LDK and MDL cultivars.

Table 5 shows that the LDL cultivar treatment produced a higher total amount of chlorophyll and was significantly differed to the LDK cultivar. However, the amount of chlorophyll between LDL cultivar and MDL cultivar was not significantly different. The effect of pepper cultivar on root biomass shows that LDL cultivar and LDK cultivar were higher than MDL cultivar root biomass. Shoot biomass of
LDL and LDK cultivars differed significantly from MDL cultivar. However, LDL cultivar was not significantly different from LDK cultivar.

\section{Interaction of Treatments}

The effect of combination treatment of manure doses and pepper cultivars on all observed variables is shown in Table 6. In general, the mean variables of the combination of treatments between doses of chicken manure and pepper varieties shows that on treatment of $5 \mathrm{~kg}$ manure dosage and Merapin Daun Lebar cultivar produces the highest plant height and stem diameter, with the value of $19.50 \mathrm{~cm}$ and $1.38 \mathrm{~mm}$. In the variables of the number of leaves and the number of nodes, the treatment of $6 \mathrm{~kg}$ of manure and Lampung Daun Kecil cultivar produced an average number of leaves and number of nodes.

The combination Lampung Daun Lebar and $7 \mathrm{~kg}$ of manure showed the lowest increase in the variables of plant height, stem diameter, number of leaves, and the number of nodes. The treatment of a dose of $6 \mathrm{~kg}$ of manure and Lampung Daun Lebar cultivar showed the highest results on leaf area, namely $184.20 \mathrm{~cm}^{2}$, total chlorophyll $(27.04 \mathrm{mg} / \mathrm{g})$, root biomass $(0.67 \mathrm{~g})$, and shoot biomass $(5.27 \mathrm{~g})$. 


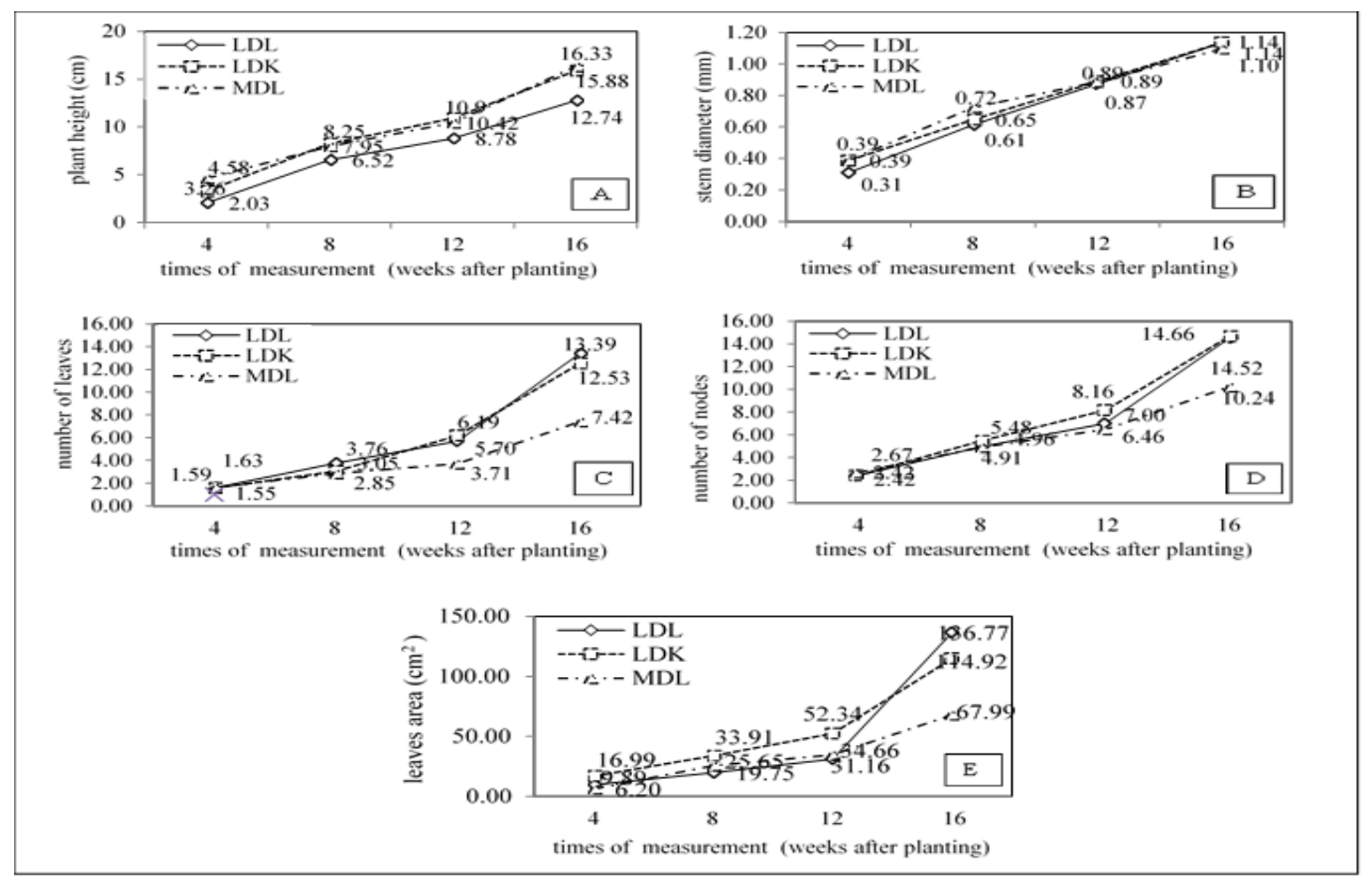

Figure 3. Rate of plant height, stem diameter, number of leaves, number of nodes, and leaves area of pepper on medium with various chicken manure doses

Table 6. Average variables growth of pepper in treatment combination of chicken manure doses and pepper cultivars

\begin{tabular}{|c|c|c|c|c|c|c|c|c|c|}
\hline \multicolumn{2}{|c|}{ Treatment } & \multicolumn{8}{|c|}{ Variables } \\
\hline $\begin{array}{l}\text { Doses } \\
(\mathrm{kg})\end{array}$ & Cultivar & $\begin{array}{c}\mathrm{PH} \\
(\mathrm{cm})\end{array}$ & $\begin{array}{c}\text { SD } \\
(\mathrm{mm})\end{array}$ & $\begin{array}{c}\mathrm{NL} \\
\text { (sheet) }\end{array}$ & $\mathrm{NN}$ & $\begin{array}{c}\text { LA } \\
\left(\mathrm{cm}^{2}\right)\end{array}$ & $\begin{array}{c}\mathrm{TC} \\
(\mathrm{mg} / \mathrm{g})\end{array}$ & $\begin{array}{l}\text { RB } \\
\text { (g) }\end{array}$ & $\begin{array}{l}\text { SB } \\
(\mathrm{g})\end{array}$ \\
\hline 5 & LDL & 12.80 & 1.03 & 14.17 & 15.17 & 136.61 & 21.28 & 0.50 & 4.87 \\
\hline 5 & LDK & 13.64 & 0.92 & 9.56 & 11.11 & 64.13 & 18.35 & 0.50 & 4.67 \\
\hline 5 & MDL & 19.50 & 1.38 & 7.50 & 9.83 & 51.89 & 21.78 & 0.23 & 2.87 \\
\hline 6 & LDL & 16.58 & 1.09 & 14.89 & 15.22 & 184.20 & 27.04 & 0.67 & 5.27 \\
\hline 6 & LDK & 16.27 & 1.33 & 18.00 & 20.06 & 179.25 & 10.61 & 0.33 & 3.63 \\
\hline 6 & MDL & 15.55 & 0.79 & 8.11 & 10.39 & 96.78 & 20.76 & 0.33 & 2.23 \\
\hline 7 & LDL & 7.31 & 1.21 & 6.17 & 9.67 & 76.24 & 25.99 & 0.60 & 4.43 \\
\hline 7 & LDK & 13.34 & 1.16 & 10.05 & 12.83 & 101.38 & 23.62 & 0.63 & 5.23 \\
\hline 7 & MDL & 16.38 & 1.05 & 6.66 & 10.50 & 55.29 & 23.48 & 0.10 & 2.37 \\
\hline
\end{tabular}

Keterangan : PH: plant height, $\mathrm{SD}=$ stem diameter: $\mathrm{NL}=$ number of leaves, $\mathrm{NN}=$ number of nodes, $\mathrm{LA}=$ leaves area, $\mathrm{TA}=$ Total chlorophyll, $\mathrm{RB}=$ Root Biomass, $\mathrm{SB}=$ shoot biomass

\section{DISCUSSION}

Analysis of pre-treated tailings shohs that it can be classified as very low in fertility (Table 1). These results confirm several previous researchers such as Sitorus et al. (2008), Sutono et al. (2018), and Hamid et al. (2017) which showed the low chemical fertility of tin mined land on Bangka Island. Amelioration of organic matter and topsoil can improve the characteristics of sand tailings so that they can be used as pepper growing media in sand tailings. According to Munawar (2011), organic matter mixed with mineral soil has a great effect on water holding capacity. The organic material is like a sponge, which can absorb and hold water up to $90 \%$ by weight. It can be used by plants, especially in sandy texture soil. Asmarhansyah (2016) states that amelioration and fertilization can improve the quality of ex-tin mining land and increase the growth and yield of some plants. According to Nurcholis et al. (2013), the addition of organic matter and 
NPK fertilizer can improve planting media and sorghum growth in sand tailings media.

Analysis of variance results (Table 3) shows that the addition of a dose of chicken manure had no significant effect on almost all variables, except leaf area. In general, sand tailings that had been mixed with chicken manure and topsoil have approached suitable conditions for pepper growth. This could be seen in the increase of plant height, stem diameter, number of nodes, number of leaves, total chlorophyll, root biomass, and shoot biomass all of which are relatively uniform. Thus it wassuspected that the low productivity of tailings had been improved by organic matter. The added topsoil contained organic-C and phosphorus nutrients (Table 1). Topsoil can reduce the proportion of sand fractions in the media because they contain higher silt and clay fractions. It is suspected that chicken manure and topsoil can reduce soil porosity, increase water holding capacity, increase $\mathrm{pH}$, and increase CEC, thereby optimizing nutrient uptake by plants. This is in line with the results of research by Sondakh et al. (2017) that organic ameliorant can improve the physical and chemical characteristics of post-mining tailings soils. The presence of organic matter would also allow microorganisms to multiply and help provide nutrients for plants. The results of Ferry et al. (2013) research show that, amelioration of mycorrhizae at a dose of 60 $\mathrm{g} /$ plant with an $80 \%$ formulation of water hyacinth compost $+20 \%$ zeolite, resulted in the best shrub pepper growth in tin mined land.

Based on the results of the analysis of variance, the effect of cultivars choices was not significant on almost all variables observed, except total chlorophyll, root biomass, and shoot biomass. In general, LDL cultivar showed higher growth compared to LDK and MDL cultivar.

Based on the mean of variables, LDL and LDK cultivar tended to be better than MDL cultivar on the growth of pepper in the sand tailings media. This can be seen in the total chlorophyll, root biomass, and shoot biomass. LDL and LDK cultivars are more adaptive and more tolerant of sand tailings media. Both cultivars were national superior cultivars, while MDL are local superior cultivar. LDL and LDK are among the superior cultivars and are recommended to be cultivated (Balittro, 2002). The results of the study Oktalgia et al. (2006) showed that the growth of LDL cuttings was better than LDK and Merapin cultivar on tin mining media. Badriyah et al. (2019) succeeded in growing LDL pepper cultivar by the application of biofertilizer in postmining tailings land.

The results showed that there was no significant interaction effect between the treatment of chicken manure doses and pepper cultivars on all growth variables. It was predicted that each treatment factor had its independent effect. It is observed that at each level of treatment produced the same response. The effect of each factor did not differ at each treatment level, so there is no interaction between the two variables.

\section{CONCLUSION}

Applying dose of chicken manure only affects leaf area growth of pepper in the sand tailing media. Pepper growth in sand tailing media which had $6 \mathrm{~kg}$ per plant chicken manure tended to grow better than the $5 \mathrm{~kg}$ and $7 \mathrm{~kg}$ per plant. Choice of pepper cultivars affects the growth in the tailing media. The Lampung Daun Lebar cultivar showed better growth than the Lampung Daun Kecil and Merapin Daun Lebar. However, the interaction between the dose of chicken manure and pepper cultivar was not affected by the growth of pepper in the sand tailings media.

\section{ACKNOWLEDGMENTS}

The authors are very grateful to the Ministry of Technology and Higher Education for funding this research through the Higher Education Flagship Research Funding Program in 2016. 


\section{REFERENCES}

Asmarhansyah. 2016. Characteristics and strategies for ex tin mining land management in the Bangka Belitung Islands. [Proceedings of the National Seminar on Agricultural Innovation Technology I in Banjarbaru, 20 July 2016].

Asmarhansyah, Badayos RB, Sanchez PB, Sta Cruz PC, Florece LM. 2017. Land suitability evaluation of abandoned tinmining areas for agricultural development in Bangka Island, Indonesia. Journal of Degraded and Mining Lands Management. 4(4): 907918.

Research Institute for Medicinal Plants and Spices (Balittro). 2002. Knowing the types of pepper varieties. Bogor: Ministry of Agriculture-Directorate General of Plantations Directorate of Spice and Refreshing Plants. http://ditjenbun.pertanian.go.id/tanregar/ halkomentar-230-mengenal-jenisjenis-varietas-4.html. [14 ${ }^{\text {th }}$ April 2015].

According to the Central Statistics Agency of the Bangka Belitung Islands Province. 2019. Bangka Belitung in Figures 2018. Pangkalpinang: BPS Kepulauan Bangka Belitung.

IAARD Agricultural Research and Development Agency. 2015. Potential for the development of Bogor Pepper in Bangkahttp://www.litbang.pertanian.go.i d/berita/one/2376/ [22th December 2015].

Soil Research Center. 1983. Criteria for Soil Fertility Characteristis. http ://www. balittanah .litbang. pertanian.go.id [19 Oktober 2016].

Badriyah, Inonu I, Asriani E. 2019. Growth of One Year Old Pepper (Pipper nigrum L.) in Post Tin Mining Land Using Different Dosage Biofertilizer. Journal of Suboptimal Lands. 8(2): 117-125.

Center for Research and Development of Agricultural Land Resources. 2016. Atlas of the semi-detail level map of mined land on Province of the Bangka
Belitung Islands. Bogor: Indonesian Center for Agricultural Land Resources. Ministry of Agriculture.

Dariah A, Abdurachman A, Subardja D. 2010. Reclamation of ex-mining land for agricultural extensification. Jurnal Sumberdaya Lahan. 4 (1): 1-12.

Ferry Y, Towaha J, Sasmita RKD. 2013. Utilization of compost of aquatic plants as mycorrhizal inoculant carriers in shrub pepper cultivation in post-mining tin lands. Jurnal Littri. 19(1): 15-22.

Hamid I, Priatna SJ, Hermawan A. 2017. Characteristics of several physical and chemical properties of soils on tin mined land. Jurnal Penelitian Sains. 19(1): 2331.

Handara N. 2011. Adaptation test of 4 varieties and 6 hopelines of soybean in red-yellow podsolic soil [graduation thesis]. Bangka Belitung: Fakultas Pertanian, Perikanan, dan Biologi. Universitas Bangka Belitung.

Inonu I, Budianta D, Umar M, Yakup, Wiralaga AYA. 2011. The response of the rubber clone to the frequency of watering in the post-mining tin sand tailings media. J Agronomi. 39(2):131136.

Inonu I, Khodijah NS, Supriadi A. 2014. Cultivation of pakchoy (Brassica rapa L.) in the tin mining tailings land with ameliorant organic fertilizer and npk fertilizer. Palembang: Proceedings of the National Seminar on Suboptimal Land [26th-27th September 2014].

Munawar A. 2011. Soil Fertility and Plant Nutrition. Bogor: IPB Press.

Nurcholis M, Wijayani A, Widodo A. 2013. Clay and organic matter applications on the coarse quartz tailing material and the sorghum growth on the post tin mining at Bangka Island. Journal of degraded and mining lands management. 1(1):2732.

Sitorus SRP, Kusumastuti Badri ELN. 2008. Characteristics and techniques for land rehabilitation after tin mining on Bangka and Singkep Island. Jurnal Tanah dan Iklim. 27: 57-74. 
Sondakh TD, Sumampow DMF, Polii MGM. 2017. Improvement of physical and chemical properties of tailings through the provision of ameliorantbased organic matter. Eugenia. 23(3): 131-137.

Sukarman, Agustian A. 2016. Survey, Land Mapping and Social Economic Analysis of the Post Mining Land. Final Report of the Operational Research Plan.
Indonesian Center for Agricultural Land Resources. Agricultural Research and Development Agency. Ministry of Agriculture.

Sutono S, Haryati U, Agus F. 2018. Soil characteristics and rehabilitation strategies for tin mined land in the Bangka Belitung Islands Province. Jurnal Sumberdaya Lahan. 12(2): 99116. 